\title{
Lições das derrotas da virada esquerdista
}

\author{
Lessons from the defeat of the turn to the Left
}

\section{Alejandro Grimson}

É doutor em Antropologia pela Universidade de Brasília, Professor Titular da Universidad Nacional de San Martín e pesquisador do CONICET (Argentina). Publicou numerosos livros sobre teoria cultural e hegemonia, sobre crenças e imaginários sociais, sobre identidades e comunicação. Além de sua vasta atuação acadêmica, intervém, habitualmente, nos debates públicos da Argentina e de outros países da América Latina. Seu último livro se intitula $O$ que é o peronismo? De Perón aos Kirchner, o movimento que não deixa de comover a política argentina (Siglo XXI, 2019).

\section{Tradução}

\section{Pablo Gonzalez}

Doutorando em Comunicação pela Escola de Comunicação da UFRJ.

Submetido em: 15/06/2019 Aceito em: 21/08/2019

\section{RESUMO}

Para o futuro dos países da América Latina e suas forças populares, é crucial aprender as lições da experiência dos governos progressistas ou de esquerda nos primeiros anos do século XXI. Sem discutir os motivos mais profundos que ocasionaram essas derrotas é impossível que essas forças não recaiam no mesmo erro. Se trata de forças e governos que transformaram as realidades de seus países, mas em muito casos continuaram fazendo política como se não as tivessem transformado. Precisamos discutir porque governos que ampliaram direitos e melhoraram a qualidade de vida não puderam dar sustentabilidade política a estes projetos de mudança.

PALAVRAS-CHAVE: Hegemonia; Classe Social; Política Argentina. 


\section{ABSTRACT}

For the future of Latin American countries and their popular forces, it is important to learn the lessons of the experience of progressive or leftist governments in the early years of the 21st century. Without discussing the reasons that caused these losses, it is impossible that these forces do not fall into the same error. These are forces and governments that have transformed the realities of their countries, but in many cases have continued to make politics as if they had not transformed them. We need to discuss why governments that broadened rights and improved quality of life could not give political sustainability to these changes like this.

KEYWORDS: Hegemony; Social Class; Argentine Politics.

É crucial aprender as lições da experiência dos governos progressistas, ou de esquerda, nos primeiros anos do século XXI, para o futuro dos países da América Latina e de suas forças populares. Há uma grande resistência em debater estes problemas entre muitos intelectuais, dirigentes e militantes, que aderem fortemente às forças que foram derrotadas. Qualquer análise ou autorreflexão são considerados como um questionamento de todo o processo e são entrevistos como somente mais uma forma de agressão contra governos, forças e dirigentes que têm sido e continuam sendo perseguidos, e inclusive sujeitos a prisão.

O paradoxo é que, sem discutir os motivos mais profundos que levaram a estas derrotas, é impossível que estas forças não recaiam nos mesmos erros. Tal como sintetizou Álvaro García Linera depois da derrota do plebiscito de 2016 na Bolívia, trata-se de forças e governos que transformaram as realidades e seus países, mas que, em muitos casos, continuaram fazendo política como se não as houvessem transformado.

Observado em termos globais, o triunfo do neoliberalismo em 1990 teve, pelo menos, uma extensão temporal de um quarto de século na Europa, Estados Unidos e na maior parte dos países da América Latina. Somente sete ou oito países da América do Sul interromperam, significativamente, essa hegemonia neoliberal. Evidentemente, tiveram grandes acertos, limitações e erros que devem ser discutidos. 
Estes debates têm sido atravessados por dois enfoques complementares que não apresentam grande interesse aqui. Por um lado, as acusações hipermidiáticas das forças de direita. Por outro lado, diferentes narrativas que postulam que se os governos houvessem sido mais radicais em termos de inclusão, na luta contra os poderes concentrados ou nas políticas ecológicas, teriam sido exitosos. Aqui, interessa-nos outra questão, especificamente política, vinculada à pergunta que abre o postulado de García Linera. Por que os governos que ampliaram direitos e melhoraram a qualidade de vida não puderam dar sustentabilidade política a estes projetos de mudança?

\section{A capacidade hegemônica}

A pergunta sobre a eficácia dos projetos políticos implica uma análise de sua capacidade hegemônica. Evidentemente, não no sentido liberal do termo que assimila hegemonia com autoritarismo, mas no sentido gramsciano de articulação de alianças que permitem a direção intelectual e moral da sociedade, a construção de um sentido comum, cedendo ao que é considerado não essencial para preservar, justamente, o essencial. A capacidade hegemônica não pode colocar-se de forma descontextualizada em algum ponto de tensões como esquerda-direita ou purismo-pragmatismo. Porque a realidade econômica, os contextos internacionais e os âmbitos internacionais mudam incessantemente. E, com eles, mudam os humores das sociedades. Nesse sentido, os pontos de articulação desta capacidade vão mudando no transcorrer do tempo. Transformam-se as diferenças sociais, territoriais, simbólicas. Portanto, as forças políticas ou os governos precisam atender a estas mudanças para serem eficazes no trabalho de articulação da heterogeneidade.

Tomemos um exemplo. Um aumento dos impostos para os setores mais ricos ou com maiores rendimentos é uma medida progressiva. Porém, as minorias afetadas vão gerar discursos apelando ao interesse geral. Dirão que este dinheiro de que o Estado se apropria era destinado ao investimento e à geração de 
empregos, ou seja, para o bem-estar geral, ao invés de dizer que era destinado a gastos luxuosos. Além disso, dirão que se alguém obtém rendimentos como resultado de seu esforço, o Estado ineficiente (porque neste discurso o Estado sempre será ineficiente) não tem o direito de roubar o dinheiro para benefício de poucos. Se tomamos exemplos reais, tanto na Argentina quanto no Equador houve reações contra impostos progressivos que afetavam às vezes 1,5 ou $10 \%$ da sociedade. Assim, ainda que uma medida mais à esquerda beneficie $90 \%$ e prejudique $10 \%$, nem sempre é gerada uma capacidade hegemônica que torne a aplicação do imposto possível.

Uma complexidade similar, ainda que por razões diferentes, é apresentada pela tensão entre "purismo" e "pragmatismo". Pode-se supor que vivemos em uma época "pragmática", e que as sociedades celebram mais resultados que dogmas. 0 exemplo mais extraordinário seria a tese de que a corrução não importa muito, desde que a economia caminhe mais ou menos bem. Porém, quando na frase "roubam, mas fazem" não sobra muito da segunda parte, então as sociedades começam a se incomodar. Pragmatismo puro, ainda que disfarçado de purismo moral. Porém, pode-se verificar com facilidade que as reinvindicações habituais a que os políticos chegam através de consenso são tão estrondosas quanto qualquer denúncia de um "pacto espúrio", se realmente chegassem a algum. Isto significa que a capacidade hegemônica é uma verdadeira arte, já que não encontra receitas nem manuais fora de sua situação histórica.

\section{Três explicações}

Há três tipos de hipóteses ou teorias acerca do motivo desta derrota. A primeira explicação refere-se à queda dos preços das commodities. Isso implica na ideia de que a "virada esquerdista" ficou sem combustível econômico. Trata-se de uma interpretação extrema e claramente economicista. Poderia supor-se que só há governos heterodoxos em conjunturas excepcionais que contradizem as teses de Prebisch sobre a constante deterioração dos termos de intercâmbio internacional

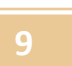


para os países periféricos. ${ }^{1}$ No entanto, a história mostra algo diferente. Muitos dos governos sul-americanos que protagonizaram a chamada "virada esquerdista" chegaram ao poder antes do boom das commodities, através de crises relacionadas à inviabilidade econômica e política do modelo neoliberal. 0 caso extremo é a aprovação da Constituição Bolivariana da Venezuela, que foi ratificada em 1999, quando o preço do barril de petróleo estava em baixa. É mais acertado dizer que o preço das commodities facilitou (ou dificultou) o processo redistributivo, do que sustentar, de modo fatalista, que não pode haver políticas redistributivas sem contextos internacionais excepcionais. Entretanto, esta tese supõe ainda que a matriz produtiva dos países seja estática, e que sua dependência de dólares é uma constante que não pode mudar. Em outras palavras, evita analisar conquistas e fracassos na mudança necessária da matriz produtiva.

Uma segunda explicação diz que a derrota foi o efeito dos meios de comunicação hegemônicos que manipulam os cidadãos com informações distorcidas ou diretamente falsas, como se existisse uma "ditadura midiática", ou apontam para o surgimento de uma nova coalizão entre estes meios, os grupos econômicos concentrados e setores do Poder Judiciário. Os processos de concentração dos meios de comunicação foram impressionantes, e as atuações do Poder Judiciário, altamente questionáveis e, em vários casos, escandalosas. Entretanto, esta hipótese não oferece uma explicação do motivo pelo qual estes ou outros poderes tiveram capacidade conspiratória na conjuntura de 2015, e não cinco ou dez anos atrás, quando houve tentativas de desestabilização em vários países (que na América do Sul haviam sido exitosos no caso do golpe parlamentar de Fernando Lugo no Paraguai). Nós não acreditamos que os meios de comunicação e outros fatores não tiveram um papel relevante. Estamos afirmando que, como argumentaremos depois, houve processos muito mais profundos e complexos. A interpretação mais extrema desta hipótese apresenta o risco de que surjam setores de esquerda que desacreditem a democracia, e acreditem que seus

\footnotetext{
${ }^{1} 0$ economista argentino Raúl Prebisch postulou que os preços dos produtos dos países periféricos tendiam a deteriorar-se em relação às exportações dos países centrais. Com o aumento do preço das commodities, devido, em grande medida, à nova relevância de países como China no comércio internacional, esta tendência se inverteu durante alguns anos.
} 
erros consistiram em não restringir as liberdades de expressão e opinião que justamente permitiram estas campanhas contra os governos. ${ }^{2}$ Esta leitura teria efeitos fatais para o futuro das forças transformadoras.

Uma terceira explicação muito frequente é a de que os processos de inclusão social e mobilidade social ascendente modificaram as demandas da população, e impulsionaram uma certa "virada direitista". Neste sentido, uma parte dos setores beneficiados pelas políticas econômicas, sociais e redistributivas, não teriam tido "consciência" política. E os governos teriam perdido popularidade por seus acertos, por suas conquistas, e por seus erros. No limite, esta interpretação despreza a relevância de qualquer debate acerca dos erros cometidos, já que os governos teriam sido vítimas de suas próprias políticas. Se tomamos a sério este argumento, trata-se de um pessimismo extremo: não há modo de construir processos sustentáveis de transformação social, já que toda melhora econômica implicaria uma "direitização" da população.

Estas três explicações têm em comum o fato de evitarem fazer um balanço político que inclua as próprias ações do governo, seus erros, suas falhas e suas limitações. Não se pode ignorar a influência dos setores poderosos. Este poder era idêntico quando estas forças triunfavam ou foram derrotadas nas urnas. Tampouco se pode deixar de levar em conta o problema da restrição externa e a baixa das commodities. Deve-se, no entanto, incluir a pergunta sobre quais foram as políticas econômicas destes governos diante destes problemas, e também como se desenvolveu a comunicação com a sociedade.

Pode-se encontrar, nestas explicações, contribuições para compreender os processos, mas elas também constituem negações sistemáticas dos problemas subjetivos. Por isso, tais explicações sofrem de duas dificuldades. Primeiro, somente enfatizam problemas "exógenos", externos à força política de governo.

\footnotetext{
20 artigo do intelectual brasileiro Marco Aurélio Garcia em defesa do caminho reformista pode ser interpretado como uma resposta ao risco de que a derrota implique a radicalização de uma vanguarda destacada das massas: '0 mal não está em fazer reformas e deixar de 'fazer a revolução' (...). 0 problema está em não inscrever um processo de reformas em uma visão de longo prazo de transformação social, política e cultural, capaz de mobilizar uma sociedade que não pode ser reduzida ao papel de espectadora". $(2017$, p. 5)
} 
Segundo, quando são potencializadas como explicações de causa única, acarretam interpretações que podem levar a conclusões políticas equivocadas e arriscadas.

Torna-se necessário uma análise política-cultural mais abrangente, incluindo necessariamente duas questões que estão excluídas daquelas explicações. Por um lado, os problemas subjetivos, "endógenos", da força política no governo. Por outro lado, os modos com que cada força reagiu justamente diante destes três fatores exógenos: a baixa das commodities, os poderes corporativos e as transformações sociais.

Observando-se a "virada esquerdista" sul-americana em seu conjunto, podese constatar que as circunstâncias políticas de onde emergiram alguns destes governos acentuaram debilidades políticas e conceituais que constituíram as caraterísticas da etapa histórica mundial. Pode-se afirmar que havia mais claridade a respeito do que se rejeitava e pouca claridade sobre qual seria a teoria econômica e política apta para enfrentar os novos desafios. Nos anos da transição entre séculos, havia dois fracassos estrepitosos à vista: o soviético e o neoliberal. Entretanto, não se percebiam nem "modelos" nem grandes conceituações. A imaginação política radical havia estado mais próxima de "mudar o mundo sem tomar o poder" (Holloway) ou das vertentes autonomistas. Estas tendências podiam oferecer opções mais ou menos eficazes para "escapar" do capital, mas não para regulá-lo ou domesticá-lo ${ }^{3}$. Não constituíam aportes para assumir o governo ou para definir políticas estatais em países fraturados e em crise.

Nosso interesse aqui é perguntar por que aquilo que estes governos se propuseram a realizar não obteve sustentabilidade política. Não faremos nem uma análise de ordem moral, nem uma crítica dos objetivos que estes mesmos governos se colocavam. Nossa pergunta principal é sobre o fracasso em dar sustentabilidade política a projetos que implicavam reformas sociais e econômicas. Para isso, nos concentraremos especificamente no caso argentino, convidando a uma comparação com os outros países.

\footnotetext{
3 Para mais detalhes, ver WRIGHT, 2016.
} 


\section{A questão das classes médias}

Para pensar as dimensões subjetivas dos processos políticos e as dificuldades para conseguir uma capacidade de hegemonia sustentável no tempo, a questão das classes médias torna-se peça chave. Na Argentina dos anos noventa, durante o auge neoliberal, era cada vez mais frequente escutar que a classe média estava "em processo de desaparecimento". Isto se relacionava com a crescente polarização social que separava ricos e pobres. Em troca, durante o kirchnerismo, assim como aconteceu em outros países sul-americanos, as classes médias se expandiram. Em geral, as políticas neoliberais tendem a elidir e debilitar as camadas intermediárias da população, enquanto as políticas redistributivas geram um piso mais alto para as camadas mais baixas (através dos programas de transferência monetária, ampliando as classes médias).

Contudo, deve-se distinguir entre as concepções sociológicas objetivas das classes médias pelo tipo de emprego, nível educativo ou níveis de inserção, por um lado, e as autopercepções de classe, por outro. Estas últimas se referem às percepções subjetivas que pessoas ou grupos podem ter a respeito de sua própria posição ou pertencimento de classe. Enquanto nas análises sociológicas objetivistas cada pessoa ou família é parte de uma classe ou estrato, nas visões subjetivas há duas diferenças cruciais. Primeiro, as pessoas utilizam outros elementos para considerar a si mesmas dentro de uma classe: ter ou não um trabalho, a mudança na qualidade do emprego, na qualidade de vida, na propriedade, no acesso de seus filhos à universidade, na possiblidade de sair de férias, ainda que sejam modestas. Segundo: para o objetivismo, cada pessoa somente pode pertencer a uma classe. Por isso, observando-se como falam os trabalhadores assalariados de si mesmos, nota-se que muitos deles consideram que podem pertencer a duas classes simultaneamente. Enquanto "classe média" e "classe baixa" são, para as pessoas, sempre termos mutuamente excludentes, "trabalhadores" e "classes médias" não o são. Não em todas as sociedades, não para todos os seus membros. Já na criação dos "trabalhadores de colarinho branco" a 
sociologia havia percebido esta distinção ou diferenciação. Contudo, quando há trabalhadores de "colarinho azul" com níveis salariais relevantes no interior do conjunto dos assalariados (como há hoje), são muito arriscadas as análises que observam somente indicadores objetivos para analisar os processos políticos.

Segundo a visão mais tradicional (todavia com peso político), apenas profissionais, pequenos comerciantes e agricultores, são classes médias. Talvez os trabalhadores de colarinho branco. Os dados da CEPAL acerca do sentimento de pertencimento à classe média baixa e à classe média na América Latina mostram o abismo entre esta concepção e os modos em que as pessoas se consideram a si mesmas. Para as medições do Latinobarómetro em 18 países da região, em 2011, 26\% se considerava "classe baixa”, 31\% “classe média baixa” e 38\% "classe média”. Observando-se o quadro da CEPAL, inclusive tomando precauções metodológicas, entende-se que é impossível construir uma estratégica adequada sem levar em conta estas percepções dos sentimentos de pertencimento da população. E menos ainda na Argentina, onde esta autopercepção de pertencer as classes médias é mais extensa no imaginário nacional do que no resto da América Latina com seus fortes contrastes.

Gráfico I

America Latina (18 países): sentimento de pertencimento à classe média e média baixa, por

países, 2011

(Em porcentagens)

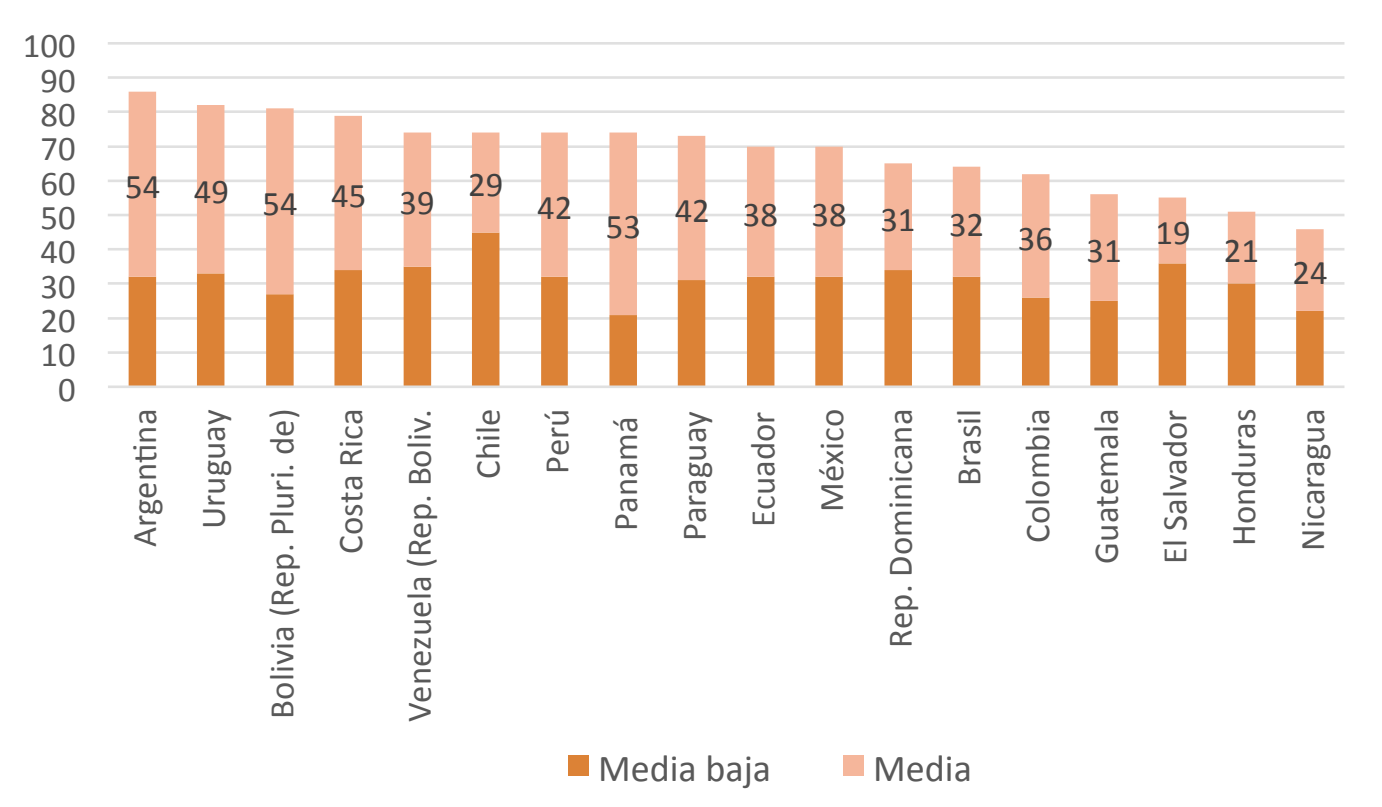


Fonte: Comissão Econômica para América Latina e Caribe (CEPAL), sobre a base de tabulações especiais da base de dados Latinobarómetro 2011.

Segundo essa mesma pesquisa, os que se consideram parte das classes médias e classes médias baixas têm uma inserção laboral heterogênea. No caso argentino, 24\% são trabalhadores autônomos, 14\% realizam trabalho doméstico não remunerado, $34 \%$ são assalariados e $28 \%$ tem outra situação laboral. Se $86 \%$ dos entrevistados na Argentina se consideram parte das classes médias ou médias baixas, um terço deste total é composto de assalariados, e um quarto de trabalhadores autônomos. Evidentemente, as classificações objetivistas e as autopercepções de classe são dois mundos incomensuráveis.

Muitas forças políticas não se deram conta desta mudança cultural na linguagem coloquial. Podem existir pessoas que consigam trabalhos fixos, conseguem habitação, adquirem uma moto ou têm um filho na universidade, e já não se consideram parte do nível social mais baixo. Portanto, não se definem como "classe baixa", mas "classe média baixa". Isto inclui grande parte dos trabalhadores sindicalizados. E dependendo do tipo de trabalho ou de outros fatores, ou simplesmente em outros contextos, o termo "baixa" pode evaporar-se, e há trabalhadores que se consideram secamente parte da classe média.

Para entender as consequências políticas destas classificações, é necessário distinguir as pessoas que tradicionalmente se consideram parte das classes médias daquelas que somente começaram a utilizar estas definições a partir das mudanças ocorridas no século XXI. 


\section{As classes médias tradicionais}

Os setores situados nas franjas mais altas da pirâmide social não somente pretendem preservar e eventualmente incrementar seus rendimentos. Uma parte significativa deles também pretende preservar e eventualmente incrementar suas distâncias simbólicas em relação aos setores que se encontram mais embaixo.

Isto coloca um problema cultural e político a qualquer política redistributiva, mesmo quando esta política não afete economicamente as classes médias altas. "Não afeta" no sentido em que não as faz perder dinheiro em relação ao passado, embora seguramente não ganhem tudo o que desejariam. Na Argentina e em outros países houve redistribuições de renda em contextos de crescimento, e não redistribuições de riqueza nem de patrimônio. De fato, por exemplo, não houve uma reforma tributária progressiva. Entretanto, a médio prazo, o fato de não ser economicamente prejudicada não reduz a oposição das classes mais acomodadas às mudanças redistributivas.

Por quê? Porque sua oposição a estes governos não deriva de cálculos puramente matemáticos acerca de ganhos ou perdas. Tal oposição está relacionada também - de modo crítico, em certas conjunturas - com sua percepção a respeito de sua hierarquia social, seu capital simbólico, suas formas de distinção em relação às grandes maiorias ${ }^{4}$.

Tais setores detestam a carga tributária, e a percebem como uma intromissão indevida do Estado em seu dinheiro, que em sua imaginação é puro resultado de seus próprios méritos, e que lhes oferece a capacidade de se distanciar em diferentes planos da vida social das grandes maiorias. Preferem gastar muito mais dinheiro em saúde, educação e segurança privada do que em um sistema tributário que garanta sua proteção social através do Estado. Desde já, sempre dirão que os impostos são roubados pelos corruptos, mesmo se seus filhos usufruem da universidade pública, se viajam por estradas ou linhas aéreas do Estado, ou se seu comércio floresce através do aumento de rendas populares.

\footnotetext{
${ }^{4}$ Para mais detalhes, ver COSTA, 2017.
} 
Nada disso será suficiente, e nem sequer visto como positivo, se estes setores já assentados sentem sua exclusividade ameaçada. Quer dizer, quando sentem que seus lugares de ócio e consumo - seus shoppings, seus bares e seus clubes, talvez mesmo as praças, as praias, os estádios e até as universidades - são crescentemente ocupados por setores tradicionalmente de rendas menores, que eles consideram inferiores e sem os quais não podem se considerar superiores. Evidentemente, aparece aqui uma dimensão cultural e identitária crucial para a política. Nestes setores tradicionais, a própria identidade de classe média pode ser ameaçada diante da ascensão econômica e do empoderamento social e político de novos setores. Se somamos a isto os extensos e profundos imaginários europeus, racistas e classistas destas classes médias assentadas, podemos compreender muitas de suas reações emocionais. As sociedades somente suportam, em cada momento histórico, certas formas de desigualdade. Há, porém, um limite socialmente tolerável para as igualdades.

Estas classes tradicionais são uma minoria em todos os países. Entretanto, são uma minoria muito relevante numericamente em alguns casos e com poder de fogo na opinião pública, na legitimidade e na criação de agendas. As perguntas políticas-culturais têm níveis distintos. Por um lado, qual o grau de homogeneidade política das classes médias? Por exemplo, o kirchnerismo implementou políticas universitárias, culturais e científicas que favoreceram setores médios. Neste plano, assemelhou-se mais ao governo Lula do que ao peronismo clássico.

Que grau e intensidade de rejeição o governo kirchnerista gerou nestes setores? Algumas expressões públicas - tanto os protestos contra a 125, quanto as manifestações de oposição do fim de 2012 e início de 2013 - mostraram a intensa passionalidade destas reações. Artistas e humoristas próximos do kirchnerismo, como Diego Capusotto, Pedro Saborido e especialmente a dupla "Telma e Nancy" duas mulheres que parodiam as posições antikirchneristas da classe média tematizaram estas reações. Cristina Kirchner, em uma entrevista realizada pelo colunista Luis Novaresio (06/08/2017), defendia a liberdade de expressão que houve durante seus governos afirmando que chegaram a pendurar cartazes que a 
acusavam de ser "égua, puta e montonera". O colunista, muito crítico em relação ao kirchnerismo, afirma que viu e condenou tais cartazes.

As acusações racistas, tão comuns na linguagem coloquial dos argentinos, não eram dirigidas nem contra Néstor nem contra Cristina Kirchner. Foram dirigidas àqueles que estes deixaram protestar (porque se negaram a reprimir) ou aos beneficiários de suas políticas. Contudo, quando a CGT opositora declarou um golpe geral em 2014 contra o imposto de renda, não se escutaram opiniões similares. A Argentina é um exemplo claro de como a política rege as classificações raciais e seu uso.

Contudo, nos termos utilizados contra Cristina Kirchner, aparecem duas dimensões: a vinculada ao sexismo e à misoginia, e a vinculada a quão vivos se encontram os anos setenta na memória dos argentinos. A belicosidade verbal destes anos, que não é exclusiva a nenhuma das partes da disputa, parecia sintomática de um país que nunca havia saldado diferenças abismais.

\section{As classes médias emergentes}

Como assinalamos antes, uma das três teses mais conhecidas para explicar a derrota de 2015 é a de que estes governos foram vítimas dos beneficiários de suas políticas. Com o crescimento, as políticas laborais e sociais, geraram maior inclusão social e maior poder aquisitivo. Isto não somente modificou os trabalhos e as rendas, como também os sentimentos de pertencimento de classe. Daí surge o aparente paradoxo da "classe média". Alguns intelectuais colocam o problema de modo fatídico: afirmam que à medida que os setores sociais mais baixos ascenderam ao consumo e a um novo poder aquisitivo, se "direitizaram".

Com um mecanismo econômico assombroso, afirma-se que as grandes maiorias nem sempre podem apoiar processos redistributivos. Por quê? Porque se diz que na medida em que estes governos geraram processos de inclusão e mobilidade social ascendente, os beneficiários destas políticas atribuíram estas 
conquistas ao esforço pessoal de cada um e não às políticas de Estado. A questão seria: para as classes médias, menos votos para os governos que as geraram. Tudo isto é uma razão objetivista e defensiva para não analisar as limitações políticas destes governos.

Assim como ocorreu em outros países, o kirchnerismo reduziu drasticamente a indigência, diminuiu até um limite a pobreza e incrementou a autopercepção de certos setores como classe média. Quando a situação mudou, estas pessoas e setores sociais já não reivindicavam o que estava resolvido, e sim apresentaram outras preocupações. Entre as novas demandas, houve várias relacionadas com serviços públicos como transporte, segurança e educação (ver Natanson, 2017) e com aspirações de consumo.

A explicação de que os beneficiários das reformas redistributivas "se direitizaram" coloca problemas conceituais sérios. Neste sentido, esta afirmação de García Linera sobre a Bolívia parece não haver sido compreendida em vários países:

surgiram outras coletividades sociais entre as classes populares e nas diversas classes médias de origem popular, mais voláteis, por residência, por estudo ou por comunidade virtual, que se movem por outras referências e interesses, muitas vezes de caráter individual. Como governo revolucionário, havíamos ajudado a mudar o mundo; porém, na ação eleitoral, em uma parte de nossas ações, seguíamos ainda atuando como se o mundo não houvesse mudado. Recorremos a meios de mobilização e de informação insuficientes para a nova estrutura social de classes e, em algumas ocasiões, empregamos marcos interpretativos do mundo que já não correspondiam ao atual momento social (García Linera, 2016).

Nesta formulação, as ações do governo geraram mudanças sociais. Estas mudanças tinham implicações culturais e políticas. E como o governo não havia compreendido esta mudança, cometeu erros que levaram a uma derrota eleitoral.

Existem transformações subjetivas na sociedade que é necessário compreender. E isto gera um problema intersubjetivo, de comunicação, quando este fato é menosprezado. Não se trata de idealizar as classes médias emergentes. Vivem, como todos, em um mundo onde parece impossível imaginar o fim do 
capitalismo, em uma cultura global que marca o prestígio pessoal e familiar em torno do consumo. Mudam sua posição social em contextos de expansão do consumo, desejam aceder a bens ou serviços com os quais somente haviam sonhado. Quer dizer, são seres humanos que vivem em uma cultura desigual. Como tais, podem desejar também distinguir-se daqueles setores que estão embaixo deles.

Ao abandonar qualquer idealização e qualquer convicção moral, nossa análise pretende devolver estes setores sociais (como todos eles) ao cenário da disputa política. Estes setores terminaram sendo decisivos, por seu peso eleitoral e porque uma parte da mudança social se constituiu justamente no surgimento desta nova classe média.

Ao não compreender estes setores, os dirigentes políticos tiveram sua capacidade de interlocução debilitada. Quanto mais se distanciaram desta população tão numerosa, mais foram moralmente condenados. Isso exacerbou a frustração de quem se autoproclamava como única representação do povo, embora não parecessem dispostos a compreender as heterogeneidades deste "povo".

Ao não assumir como própria a construção de uma nova agenda para esta etapa e concentrar o discurso em reivindicar as conquistas governamentais, o kirchnerismo corria o risco de que uma direita que se apresentasse como "moderna", com um marketing do catching all, apropriasse-se do discurso da mudança. De fato, uma parte do êxito cultural e político da "revolução neoconservadora" dos anos oitenta assentou-se justamente sobre esta operação cultural: colocar as esquerdas na defensiva e apropriar-se do discurso do novo.

Os governos pós-neoliberais fabricaram "classes médias" e não compreenderam estas mesmas classes médias. Deveria resultar daí que um projeto que não inclua as demandas de serviços e de transparência e que não satisfaça certos níveis de consumo terá grandes dificuldades se pretender ser majoritário na Argentina. Na realidade, poderia sê-lo depois das novas consequências neoliberais, porém somente enquanto repararem estes danos. Se quiser ir mais além, precisa 
compreender as percepções, sensibilidades e demandas de uma sociedade com mais setores médios e com menor exclusão.

As dinâmicas da aspiração produzem não somente novas demandas, mas também identificações de setores socioeconômicos menos privilegiados com outros mais privilegiados. Este problema muito real não se resolve rechaçando e confrontando a "aristocracia operária" com as "classes médias". Deve-se abordar as múltiplas causas do mal-estar (que pode incluir problemas governamentais como corrupção, teimosia, verticalidade, atitudes autoritárias, ineficácia), analisando-as sem cegueiras. Ou seja, o desafio é encarar o árduo trabalho de desarticular as equivalências opositivas, ao invés de fomentá-las com binarismos que minam a própria capacidade hegemônica

Aquelas forças políticas que se imaginam como representantes das "grandes maiorias" precisam desenvolver uma sensibilidade que permita compreender os sentimentos e autopercepções de classe das populações que pretendem representar.

\section{A batalha cultural}

As distintas questões que temos abordado até aqui se relacionam com outro problema: a concepção da batalha cultural como "dicotomização" de identidades. As matrizes culturais que impulsionaram dinâmicas de polarização binárias, reclamando a identificação do povo com os atores políticos que pretendiam representá-lo, perderam de vista as incidências paradoxais da cultura política.

Assim como existem a restrição externa (falta de divisas) e a restrição interna (oposição de poderes corporativos), há uma terceira restrição que os atores sociais ignoram: a restrição cultural. Os seres humanos são seres culturais, incluindo os empresários importantes, os dirigentes sindicais ou os presidentes. Também eles têm um sentido comum, como os ministros e funcionários. Também 
eles falam uma língua, entre milhares de línguas que existem no mundo. E cada língua (como cada dialeto político) permite e impede de pensar e dizer.

Quando os políticos não registram a restrição cultural, a cultura opera sobre eles mais que eles sobre a cultura. A linguagem, os símbolos instituídos, os imaginários sociais e sua própria imaginação sobre o que é desejável e o que é possível constituem um limite cultural para a ação pública.

As crenças sociais a respeito do Estado, da educação, da inclusão e da desigualdade estabelecem limites para as políticas públicas. Por um lado, inumeráveis avanços podem evaporar porque não se assentam sobre mudanças profundas no senso comum. As mudanças econômicas e políticas somente podem ser duráveis quando se enraízam em profundas transformações culturais. Por outro lado, também uma política de livre mercado e contra os sistemas de proteção social somente é viável gerando as condições culturais que as tornem possível.

Por exemplo: é evidente que, até 2015, alguns setores das direitas latinoamericanas, após anos de fracassos, haviam concluído que não poderiam disputar as eleições com chances de ganhar sem se apresentar de modo menos virulento diante do eleitorado, aceitando algumas conquistas dos governos de esquerda e moderando seu discurso. Em sua campanha eleitoral, Macri cedeu diante das convicções sociais em favor de um Estado ativo. Esta coesão discursiva não indica nenhuma mudança ideológica das direitas, porém assinala mudanças culturais profundas nas sociedades e nas estratégias políticas das direitas naquele momento. Em um contexto diferente, começaram a vislumbrar outras estratégias, a mais inflamada das quais tendo sido a de Jair Bolsonaro no Brasil.

Se há algo evidente é que estamos presenciando há vários anos um modo equivocado de entender a "batalha cultural". As lutas pelos valores e imaginários não se ganham nem com boas intenções, nem ocupando o lugar "certo". Tampouco se deve exagerar o lugar da "informação", como se se tratasse de uma luta entre dados, ou entre verdades e mentiras. As verdades sobre as conquistas sociais podem ser corroídas quando se perde credibilidade em questões de Estado, tal 
como no caso da manipulação das estatísticas ou da falta de transparência. Quando o termo "transparência" foi apropriado pela direita, a esquerda perdeu uma batalha pública relevante.

Além disso, os modos de vinculação entre os líderes políticos e a população têm um papel decisivo. Questões como o sacrifício, o agradecimento, a honestidade, a humildade ou a soberba são cruciais na dimensão cultural. A população se cansou de toda confrontação e se ilude com um consenso vazio? Ou percebeu uma confrontação identitária que a exigia mais do que a que estava disposta a dar quando começou a encontrar resultados menos efetivos que antes?

Nossa hipótese é que a épica kirchnerista foi tomando distância diante das crescentes restrições econômicas e suas consequências. Porém este erro não significa que os argentinos estavam prontos para retomar a épica neoliberal dos anos noventa. Por isso, como em 2015, a direita ganhou sem uma virada direitista, e outras confrontações culturais continuaram intensificando-se.

A questão simbólica de "defender o que foi alcançado", aguçando os contrastes com a crise de 2001, deixou o kirchnerismo (que nunca quis debater reformas tributárias, nem leis que permitissem maior transparência à política, nem a autonomia do INDEC) aferrado a um passado que a sociedade percebia como tendo realizado conquistas, mas também como tendo gerado situações inaceitáveis que seguiam sendo defendidas.

A primeira derrota aconteceu quando a direita se apropriou do discurso de mudança e futuro. Assim ocorreu com as revoluções neoconservadoras dos anos oitenta. Os êxitos neoliberais começam quando o discurso sobre a educação ou a saúde pública se torna exclusivamente defensivo, e quando se renuncia a produzir uma agenda própria de mudança.

Desde 2012, em um contexto de crescentes dificuldades econômicas e de intensificação, a divisão política da sociedade - diferentemente dos anos anteriores, em que o oficialismo havia sido beneficiado - começou a produzir efeitos distintos. 0 terço da sociedade que nunca havia sido kirchnerista nem 
antikirchnerista foi recusando cada vez mais o estilo do governo. Somente no final o oficialismo reconheceu algo disto. A presidenta Cristina Kirchner aludiu ao fato de que talvez seu estilo pessoal não tivesse agradado. Insistiu, porém, que se tratava de discutir a substância, e não as formas. Posteriormente, em sua campanha eleitoral de 2017, fez uma autocrítica bastante limitada: "alguém chegava em sua casa, ligava a televisão e via que a presidenta era uma pessoa nervosa, contraída ou apagada, o que não era bom para um presidente. Não sabia que ia ser atacada e criticada por causa de formas, invalidando o que era importante."5

A maior parte deste terço da sociedade viu algo substancial nas formas. Assim, as longas e frequentes emissões em cadeia nacional geraram um efeito bumerangue. Enquanto o governo considerava que somente assim podia comunicar suas conquistas, amplos setores sociais começaram a se incomodar com os discursos longos, dedicados em grande medida a uma confrontação que crescentemente se tornava remota na medida em que começou a se desconectar das vidas cotidianas.

Isto não significa que os resultados desta disputa não tiveram repercussões objetivas na vida da população. Pelo contrário, teriam impactos imensos. 0 fato, porém, é que um governo que previamente soube comunicar muito bem algumas destas questões aferrou-se a respostas equivocadas em seus últimos anos. Havia muitas questões como a falta de transparência das estatísticas públicas, disputas de mineração e repressão de um povo indígena. Seus opositores mais entusiastas afirmaram que todos estes fatos definiam o kirchnerismo. Porém, convém questionar, na análise - seja em que governo for -, que elementos são essenciais para um projeto político e que medidas são consequências de erros de interpretação ou de gestão. Isto seria tomar parte em um debate sobre "a essência" do kirchnerismo, que é distante de nossas preocupações aqui. 0 fato é que estas decisões levaram o kirchnerismo a uma crescente distância e a um crescente desgaste, erodindo a sua credibilidade.

\footnotetext{
${ }^{5}$ Cristina Fernández de Kirchner, entrevista com Luis Novaresio, 6 de agosto de 2017.
} 
Tudo isso indica que, de maneira crescente depois dos 54\% de 2011, o governo sobressaltado já não pôde superar as restrições culturais e se tornou vítima de condicionamentos históricos argentinos. Traços que em diferentes circunstâncias atravessaram o peronismo e o anti-peronismo: a dicotomia, a incompreensão dos apoios sociais que o adversário consegue obter, a identificação do "ter razão" com o triunfo assegurado, o crescente isolamento e uma verticalização potente, completamente ineficaz em termos de êxitos políticos.

O paradoxo é que não se pode esperar de uma cultura política como a Argentina a sustentabilidade de um projeto de transformação. Trata-se de uma cultura que gera dicotomias tão absolutas, formuladas de modo que torna impossível incorporar elementos das críticas dos adversários, que leva à derrota projetos com conquistas inegáveis. Uma cultura obcecada com seus passados remotos do século XIX, uma cultura onde se aninham ilusões primeiro-mundistas, uma cultura política onde nenhum ator relevante obceca-se em ultrapassar o duplo padrão, e assim podemos seguir.

Entretanto, não há projeto de mudança - nem liberal, nem de justiça social, nem nenhum outro - que possa desenvolver-se sem apoiar-se em dimensões vivas da própria cultura política. Por isso, um projeto de desenvolvimento com justiça social requer, ao mesmo tempo, sustentar-se nos aspectos positivos da cultura argentina e apontar a transformação de problemas muito arraigados na tradição nacional. Por acaso alguém que provém desta mesma cultura poderia transformála? Existe essa possibilidade, mas é preciso explicá-la. Somente seria factível implantando, por pressão de outros atores sociais e institucionais, um olhar crítico e reflexivo sobre a própria cultura, compreendendo que sem a transformação das bases mesmas da imaginação social e política, tudo que é sólido se desmancha no ar.

\section{Os três terços}


A sociedade argentina, nos últimos anos, esteve dividida em três setores. Anteriormente a 2015, aproximadamente um terço era fortemente oficialista, outro era opositor, e outro era formado por eleitores sem preferência fixa, indecisos ou que mudaram de opinião. Muitos deles votaram em Cristina Kirchner em 2011 e em Mauricio Macri em 2015. Esta divisão em três manteve-se por muitos anos, ainda que com variações na porcentagem de adesão a cada polo.

Durante os últimos anos do kirchnerismo, o governo se dirigiu cada vez menos ao terço dos indecisos, que resultava decisivo. Cada vez mais radicalizou seu discurso em termos de amigo/inimigo, reforçou a convicção dos já "convencidos" e gerou uma crescente distância em relação a este setor. Os discursos de Cristina Kirchner em cadeia nacional, alguns programas de televisão, a publicidade oficial e outros símbolos conformaram o que a oposição designou desdenhosamente como o "relato kirchnerista", que, do ponto de vista do kirchnerismo, contribuiu com a outorga de um caráter épico por parte das políticas oficiais e a forjar um setor de adesão intensa. Esse discurso apresentou, até o final do segundo mandato de Cristina Kirchner, dois problemas. Por um lado, a épica exacerbava-se, enquanto as percepções sociais das dificuldades da realidade econômica iam em sentido contrário.

Por outro lado, a institucionalização de mentiras e distorções em relação a algumas políticas e problemas debilitava a capacidade do governo de defender seu relato. Com efeito, desde 2007 o governo havia destruído uma parte das estatísticas oficiais, já que havia manipulado o índice de inflação, que acabou sendo uma tergiversação, assumida por todos, que dizia que a inflação era a metade ou menos do que era na realidade.

O governo negava a inflação real, superior a $25 \%$, não somente em seus discursos, mas também na ausência de explicações sobre as causas e as possíveis políticas que a combateriam. Os funcionários chegaram a ser proibidos de admitir que havia inflação. Somaram-se outras negações: a da pobreza, quando o governo se negou a publicar as estatísticas; o persistente aumento da criminalidade. Enquanto isso, eram os setores médios e mais pobres que corriam maiores riscos 
de serem vítimas destes problemas. Esta negação de aspectos vividos cotidianamente nas ruas combinou-se com a negação dos atos de corrupção.

Ao relato antikirchnerista que depreciava qualquer conquista alcançada sob o grito de "insegurança, inflação, corrupção", respondia-se com listas de conquistas, como se fosse um diálogo de surdos. Quando os argentinos viram pela televisão o ex-secretário de obras públicas, José López, tentando esconder bolsas com milhões de dólares em um convento, de madrugada, tudo se colocou em dúvida, inclusive as conquistas indiscutíveis do governo. E como em muitos outros países (por exemplo, o Brasil), a questão da corrupção converteu-se estranhamente em uma bandeira da direita. Estranhamente porque, não somente no caso do Brasil e da Argentina, há forte corrupção nessas forças que se apresentam como representantes da "ética", incluindo denúncias nos Panama Papers, contratos obscuros com o Estado, contribuições falsas a campanhas eleitorais, propinas vinculadas a obras públicas. Estranhamente porque, na América do Sul, é impossível destacar a corrupção da história do capitalismo e do neoliberalismo. Mesmo assim, as forças neoliberais, ao menos durante um tempo, se apoiaram nesta bandeira como uma hipocrisia e um duplo padrão impressionante, porém eficaz.

Talvez este tenha sido um dos efeitos mais devastadores das ofensivas antikirchneristas. Diante da crise, o governo, ao invés de distinguir o que era inegociável do que havia de razão, ao invés de distinguir o essencial e o não essencial, tendeu a se afastar de qualquer oposição da mesma forma, e contribuiu para uma polarização que tornava a disputa política cada vez mais difícil. A posição discursiva gerava uma crescente distância entre as percepções da sociedade e as percepções do governo. A luta política debilitou um governo que se apresentava como insensível a problemas reais.

Durante mais de uma década, com melhores e piores momentos, o kirchnerismo havia conseguido articular setores heterogêneos. Por isso havia se tornado hegemônico. Quanto mais homogêneo se tornou o kirchnerismo depois de 2011, menos apoio conseguiu conquistar. 


\section{Os limites hegemônicos do "populismo"}

Até aqui, evitamos propositadamente mencionar o conceito de "populismo", já que se converteu em uma noção tão polissêmica e enclausurada que às vezes obscurece o debate muito mais do que o clareia. Se, por um lado, o conflito social é inerente a todas as sociedades complexas, democráticas ou não, o populismo a la Laclau $(2005)^{6}$ tende a organizar este conflito através de um dispositivo de polarização muito específico. Se o populismo se considera, obviamente, como representante do "povo", sua alteridade não pode ser outra senão o "antipovo". Assim, a divisão do campo político se coloca crescentemente em termos identitários e não em termos de acesso a direitos. Esta distinção não pode ser compreendida sem aceitar-se a identidade populista implicada na heterogeneidade econômica, social, cultural e política dos setores subalternos. 0 que implica que esta identidade deveria se constituir sempre em expansão e com alianças com aquilo que desenvolve.

O paradoxo do discurso populista é que este se sustenta no postulado de sua própria representação política do povo, da nação, da totalidade, para enviar ao território do antipovo e da antipátria todo o excluído de suas próprias fronteiras identitárias. É muito óbvio que em contextos eleitorais qualquer experiência política ou projeto disputa a obtenção de mais da metade dos votos. Neste sentido, a ideia de que a metade poderia ser a totalidade introduz uma instabilidade representativa e, ao mesmo tempo, um distanciamento dos setores mais próximos da metade excluída.

Gerardo Aboy Carlés propõe pensar o populismo a partir da coexistência de duas tendências contraditórias: "a ruptura fundacional (que dá lugar à inclusão do excluído), mas também a pretensão hegemônica de representar a comunidade como um todo (a tensão entre plebs e populus; isto é, entre a parte e o todo)" (Aboy Carlés, 2010).

\footnotetext{
${ }^{6}$ Refiro-me aqui especificamente à concepção sobre o populismo desenvolvida por Laclau em seu livro La razón populista, que implica continuidades e rupturas em relação a abordagens anteriores.
} 
Ao mesmo tempo, na medida em que realmente os dirigentes e militantes de movimentos com influências populistas acreditam representar o todo, carecem de ferramentas teóricas e políticas para compreender a possibilidade de uma derrota eleitoral. Pode haver derrotas em lugares específicos, que serão vistos - a partir deste momento - como centros antipopulares, o que por si mesmo aumentará a distância entre o movimento populista e estes territórios. Uma cidade que se ganhou em uma etapa e se perdeu em outra pode ser estigmatizada como "de direita". Porém a derrota nacional é impensável. Donde a necessidade de tornar absolutos os fatores exógenos para explicá-la.

Um problema adicional, derivado desta concepção da representação política, refere-se à naturalização da ideia de povo e de seus interesses, e da consequente instituição do sujeito político. Neste sentido, a crítica de Quijano (2015) à noção de classe do materialismo histórico, por sua naturalização e homogeneização, é totalmente aplicável a essa ideia de povo. Qualquer noção de "trabalhadores" ou "assalariados" alude, inevitavelmente, a uma realidade estrutural heterogênea. A noção de povo intensifica o caráter heterogêneo desta referência, já que, inexoravelmente, tem duas acepções. Ou bem incorpora os assalariados, os trabalhadores precarizados, os indígenas, os afro, os desocupados, o trabalho não remunerado, a dimensão de gênero e as classes médias, ou expulsa algum destes setores. Em outras palavras, ou aceita a heterogeneidade constitutiva do "povo" ou fabrica uma homogeneidade excludente.

Por outro lado, não existe naturalidade alguma na constituição do sujeito político, nem em termos de classe, nem étnicos, nem raciais, nem populares. Como trabalho de articulação, é somente uma possibilidade histórica que, quando se constata, implica que aquilo que devém "povo" é um conjunto altamente heterogêneo (em termos estruturais, econômicos, culturais e de poder). "Devém povo" porque "povo" como representação nunca é um fato dado, senão uma potência contingente.

Nos momentos de maior efetividade hegemônica, no sentido de englobar a heterogeneidade que o transbordava, o kirchnerismo vinculou suas políticas 
econômicas, sociais ou de direitos humanos às necessidades nacionais. Nos momentos de menor efetividade hegemônica, buscou relacionar - inversamente suas necessidades políticas com as necessidades da nação.

Para entender como operou este deslocamento entre as principais referências políticas, pode-se estabelecer uma sequência esquemática. Diante de decisões aparentemente arriscadas, mas que se revelaram muito acertadas (como a reestruturação da dívida ou a rejeição do ALCA), ou diante de medidas mais polêmicas, que o governo considerava imprescindíveis por razões fiscais ou da própria governabilidade, cada vez mais perceberam ou interpretaram ações de destituição de corporações econômicas, institucionais ou midiáticas. Ao invés de enfrentarem estas ações buscando ampliar sua base de sustentação social e política, sobretudo após o êxito eleitoral em 2011, intensificaram a polarização, apontando uma crescente homogeneização da própria força política. Convencer ainda mais os já convencidos. Ao invés de fortalecer, isto debilitou o kirchnerismo.

Se houvesse uma identificação plena entre o povo e o movimento político, o primeiro não poderia expressar-se senão através do segundo. Porém se, como temos mostrado, o "povo" é sempre uma heterogeneidade irredutível a uma identidade política, em todos os contextos há mais ou menos setores populares não peronistas ou não kirchneristas. Se um discurso populista reclama o monopólio da representação homogênea do povo, gera uma rispidez, uma distância, um malestar dos setores não identificados. À medida que esta fronteira se aprofunda, gera-se uma ruptura e uma confrontação. A interpretação identitária desta tensão a coloca na dicotomia povo e antipovo. Porém isso não faz mais do que aprofundar, por motivos estritamente políticos, uma divisão que é imaginada de outra maneira.

Isso gera processos de adesão e expulsão de dirigentes, agrupamentos, sindicatos e indivíduos. A fidelidade tende a ser total, ou a confrontação tende a se tornar absolutista. A divisão ou passagem para a oposição de líderes e grupos foi desprezada pelos líderes kirchneristas no estágio de expansão da base eleitoral. Porém tornou-se um problema de primeira magnitude diante das confrontações eleitorais. 
Essa concepção manifestou-se ainda depois da derrota de 2015. Um dos cantos kirchneristas que mais energizaram suas próprias fileiras foi 0 "voltaremos". Quando setores sociais crescentes começaram a opor-se às medidas econômicas e políticas do governo de Macri, este slogan não poderia unificar, senão dividir a oposição. A ideia de que a reivindicação de sua identidade política deveria pavimentar o caminho para o retorno não dá conta de que esta afirmação identitária não somente gerou lealdades, mas também rupturas. E que essas divisões, cuja resolução aparece como uma condição para a derrota de Macri, não podem ser reparadas a partir de uma lógica identitária.

Essa política identitária concebe as sociedades como partidas em duas metades. Por isso mesmo, perde de vista o amplo setor que não adere a nenhuma das principais alternativas políticas. Também leva ao erro de construir uma épica que nega os problemas que a sociedade percebe. Nem sempre se alcançam discursos e relatos adequados sobre estes problemas. A paixão pode se voltar contra seus enunciadores quando amplia a distância entre discurso e experiência social. Esta distância se traduz em desconfianças. Neste sentido, todo governo necessita construir uma narrativa própria e propô-la à sociedade. Porém a pergunta política é: até que ponto este relato é inverossímil? Até que ponto é acreditado ou não por setores da população?

Por trás de estratégias políticas equivocadas, houve problemas de conceituação. A dicotomização pode funcionar contra o ALCA, o FMI ou os genocidas. Porém quando o "nós" refere-se a uma corrente política, reduz os espaços intermediários e os matizes, expulsa as críticas pontuais, as diferenciações específicas. Nem sectarismo nem as formas de autoproclamação contribuem para generalizar alianças que construam uma maioria que deveria incluir outras identidades políticas ou agrupamentos sem identificação partidária.

Para construir estas maiorias o caminho a recorrer é muito diferente. Tratase de vislumbrar as reações populares em relação às políticas neoliberais em toda sua heterogeneidade de setores, identidades, tradições, organizações e repertórios de luta. O desafio é que este mal-estar e esta confrontação com os planos 
neoliberais, por tudo o que temos explicado, não tem uma deriva mecânica no plano da representação política. Para ultrapassar o abismo que pode haver entre a oposição a estas políticas e uma representação política, o primeiro passo é reconhecer as heterogeneidades constitutivas para construir formas de articulação que expressem esta pluralidade e, deste modo, possam ser efetivas.

Cada um dos peronismos em ascensão constitui o capítulo de uma articulação de heterogeneidade. E cada uma das derrotas dos peronismos é um caso de ruptura ou estalido desta heterogeneidade.

Néstor Kirchner não poderia ter chegado à presidência sem o protagonismo de uma aliança política muito heterogênea, onde as novas ideias e rostos misturam-se com outros mais conhecidos e tradicionais. Embora a ideia de pertencimento a uma geração (a de setenta) que havia perdido a vida tentando mudar o mundo tenha formado parte de quadros relevantes do governo, houve amplos setores que o integraram sem ter vínculo algum com esta sensibilidade ou esta perspectiva. Tal como ocorreu em outros países, os acordos que viabilizaram governos dispostos a romper a "normalidade neoliberal" incluíram vertentes e lógicas distintas, desde a realpolitik de setores políticos tradicionais, até complexas relações com movimentos sociais. 0 desafio de conceituar a heterogeneidade das próprias forças políticas é crucial para preservar ou ampliar esta heterogeneidade, ou para reduzir os riscos centrífugos de ruptura.

Se, tal como ocorreu, esta heterogeneidade das forças e setores foi uma condição necessária dos governos kirchneristas, isto significou que a sustentabilidade de seus projetos estava constantemente desafiada. Porque, além de tudo, seus adversários também jogaram e tentaram gerar rachaduras e quebras na articulação dessa heterogeneidade.

Quando este elemento se perde de vista, cresce a tentação de acreditar que as lideranças pessoais fortes expressam forças políticas homogêneas. Se fosse assim, o líder precisaria apenas pôr em cena seu carisma para convencer a sociedade de uma medida ou de uma postura. Porém, as intensidades com as quais 
os setores da sociedade escutam estas palavras são múltiplas. Também o são em conjunturas históricas diferentes. Além disso, em alguns momentos, setores sociais e políticos dessas alianças podem elevar vozes mais ou menos dissonantes. Diante disso, a pior atitude política é a condenação moral desta dissonância, já que é negar o sintoma de processos profundos, de heterogeneidades constitutivas.

Em resumo, acreditamos haver mostrado que ao conceituar a política como intersubjetiva, não é possível deixar de considerar a força e as capacidades do adversário. Uma situação não se define por um único elemento. Por isso, torna-se necessário compreender os erros e acertos das próprias forças. Uma coisa é falar de "erros e acertos ideológicos", outra coisa é falar de "erros e acertos de construção de hegemonia". É forte o risco de não compreender a relevância da capacidade hegemônica.

Para esta construção política, é necessário levar em conta as subjetividades múltiplas, as configurações de sensibilidades, as polissemias, excedentes de sentidos, duplos significados. Quer dizer, há significados contraditórios. Aquilo que move, por exemplo, as bases próprias, pode aumentar o distanciamento das bases adversárias. Se são forças relativamente equivalentes, a pergunta recai novamente sobre a intervenção sobre os não convencidos. É de pouca serventia que os convencidos estejam hiperconvencidos se os outros se deslocam para uma posição adversária.

Nas maiores disputas, uma questão central é, do ponto de vista de diferentes atores sociais, que interesse representam as medidas. Também é muito relevante quem aparece como responsável pelos níveis e graus de conflito. Pode acontecer que setores da população simpatizem com certas medidas, mas não com o alto custo de conflitos que implica alcançá-las.

É nestes terrenos de construção de significações e de subjetividades que se joga uma parte crucial da batalha cultural e da disputa hegemônica. 


\section{Referências bibliográficas}

ABOY CARLÉS, Gerardo. Las dos caras de Jano. Acerca de la relación compleja entre populismo e instituciones políticas". In: Pensamiento Plural vol. 7, 2010.

ADAMOVSKY, Ezequiel. Historia de la clase media argentina. Buenos Aires: Planeta, 2010.

LACLAU, Ernesto. La razón populista. Buenos Aires: Fondo de Cultura Económica, 2015.

; MOUFFE, Chantal. Hegemonía y estrategia socialista. Madrid: Siglo XXI, 1987.

KULFAS, Matías. Los tres kirchnerismos. Buenos Aires: Siglo XXI, 2016.

OMAR, Acha; QUIROGA, Nicolás. El hecho maldito. Rosario: Prohistoria, 2012.

WRIGHT, Eric. “Destruir, domar, escapar, erosionar? Cómo ser un anticapitalista hoy". Disponível em: www.sinpermiso.info/textos/la-clase-importa. Acesso em 30 set. 2019. 